\section{Anticancer Compounds from Chaetomium globosum}

\section{Moubasher Hani* and Hamed Eman}

Department of Botany and Microbiology, Faculty of Science, Cairo University, Giza, Egypt

*Corresponding author: Botany and Microbiology Department, Faculty of Science, Cairo University, Giza, Egypt, E-mail: Moubasher54@hotmail.com Rec date: Feb 28, 2015; Acc date: Apr 21, 2015; Pub date: Apr 23, 2015

Copyright: (c) 2015 Hani M, et al. This is an open-access article distributed under the terms of the Creative Commons Attribution License, which permits unrestricted use, distribution, and reproduction in any medium, provided the original author and source are credited.

\begin{abstract}
The present work resulted in isolation and purification of two potential anticancer compounds from Chaetomium globosum isolated from Egyptian soil. The two compounds were tested against Michigan Cancer Foundation-7(MCF-7) breast cancer cell line and Hepatocellular carcinoma, Human (HEPG-2) a human liver carcinoma cell line and showed inhibition effect on the proliferation of two cell lines. The structures of the two pure compounds were elucidated by HNMR and Mass spectroscopy as methyl 9-dihydro-8-trihydroxy-9-oxo- $\mathrm{H}-$ xanthene-1-carboxylate as a member of xanthones and (E)-methyl 2-hydroxy-6, 6-dimethyl hept-3-enoate.
\end{abstract}

Keywords: Chaetomium globosum; MCF-7 cell line; HEPG-2 cell line; Anticancer compounds; Cytotoxicity; Xanthones

\section{Introduction}

Chaetomium Kunze is a large genus of the Chaetomiaceae Winter Sordariales Chad. Ex D. Hawksw. and O. E. Erikss., Ascomycota which comprises more than one hundred species. Chaetomium has been reported to play a major role in the decomposition of cellulose-made materials. As well as being a contaminant, Chaetomium spp. are also encountered as causative agents of infections in humans. A few cases of fatal deep infections due to Chaetomium atrobrunneum have been reported in the immune compromised host. Other clinical syndromes include brain abscess, peritonitis, and onychomycosis [1,2]. Secondary metabolites are organic compounds that are not directly involved in the normal growth, development, or reproduction of an organism. Unlike primary metabolites, absence of secondary metabolites does not result in immediate death [3]. One of these secondary metabolites is xanthones, phomoxanthones A 99 and B 100, two novel xanthones dimmers both exhibited cytotoxic activity against KB cells, BC- 1 cells and non-malignant cells [4,5] Isolate four new metabolites, chaetomugilins $\mathrm{P}-\mathrm{R}$ and 11-epi-chaetomugilin I from C. globosum which significantly inhibited the growth of cultured P388, HL-60, L1210 and KB cell lines. Petroleum ether and ethyl acetate extracts of the liquid culture of $C$. globosum showed potent in vitro antioxidant activity, proved potent antibacterial activity and cytotoxic effect on human hepatocellular carcinoma cell line (HEPG-2) [6]. A novel cytotoxic chlorinated azaphilone derivative named chaetomugilin $\mathrm{D}$, with chaetomugilin $\mathrm{A}$, chaetoglobosins $\mathrm{A}$ and $\mathrm{C}$, isolated by a bioassay-guided fractionation from the EtOAc extract of C. globosum $[7,8]$ Isolate a new metabolite named chaetoglobosin $\mathrm{X}$, together with three known compounds erogosterol, ergosterol $5 \alpha, 8$-peroside and 2methyl-3-hydroxy indole from $C$. globosum isolated from medicinal plant Curcuma wenyujin. Chaetoglobosin X exhibited a broader antifungal spectrum and showed the strongest cytotoxic activity against $\mathrm{H} 22$ and MFC cancer cell lines. Bioassay-guided fractionation of a cytotoxic EtOAc extract of the fungal strain, C. globosum, inhabiting the rhizosphere of the Christmas cactus, Opuntia leptocaulis, of the Sonoran desert was carried out by [9], where they afforded a new dihydroxanthenone, globosuxanthone A, a new tetrahydroxanthenone, globosuxanthone $\mathrm{B}$, two new xanthones, globosuxanthone $\mathrm{C}$ and $\mathrm{D}, 2$-hydroxyvertixanthone, and two known anthraquinones. Globosuxanthone A was found to exhibit strong cytotoxicity against a panel of seven human solid tumor cell lines, disrupt the cell cycle leading to the accumulation of cells in either $\mathrm{G} 2 / \mathrm{M}$ or $\mathrm{S}$ phase, and induce classic signs of apoptosis. Previous studies of $C$. globosum resulted in isolation of chaetomin [10], chaetoglobosins A-B [11], C-F [12], G and J [13] Q, R, and T [14], 19O-acetylchaetoglobosins B and D, TAN- 142 [15], heptelidic acid [16], dethio-tetra (methylthio) chaetomin [17], chaetovirindins A-D [18], prenisatin [19], PFI 138 A and B [20] chaetomanone and echinulin [21].

\section{Material and Methods}

\section{Source of Chaetomium globosum}

Chaetomium globosum were isolated from soil samples collected from Cairo University, Giza Governorate ( $5 \mathrm{~cm}$ depth). Serial dilution method was used for isolation of $C$. globosum on Czapek's media supplemented with carboxy methyl cellulose (CMC) as a sole carbon source and the medium was adjusted at $\mathrm{pH}$ 5.4. After inoculation on sterilized plates at $28^{\circ} \mathrm{C}$, the grown fungal cultures were carefully and aseptically sub-cultured onto potato dextrose agar media (PDA) Fluka 70139 adjusted at $\mathrm{pH} 5.4$ to obtain pure fungal culture. The fungal isolates were identified at Assiut University Mycological Center (AUMC), according to [22], using colony appearance and microscopic characteristics.

\section{Extraction and isolation of anticancer bioactive compounds}

Identified C. globosum was inoculated in 1000 ml flasks each containing $300 \mathrm{ml}$ potato dextrose broth by taking six agar disks with 1 $\mathrm{cm}$ in diameter. The flasks were incubated for 30 days at $28^{\circ} \mathrm{C}$. For Extraction of anticancer bioactive compounds, $120 \mathrm{ml} \mathrm{MeOH}$ was added to contents of each flask and briefly sonicated. The resulting mixture was filtered through Whitman No.1 filter paper. The filtrate was concentrated to half of its original volume and then extracted by using $60 \mathrm{ml} \mathrm{EtOAc}$ for each $100 \mathrm{ml}$ of the filtrate. Evaporation under reduced pressure afforded EtOAc crude extract. 


\section{Test for anticancer potentiality of EtOAc crude extract on different cell lines}

Cytotoxicity test for crude extract was carried out at Vacsera, Egypt using Sulforhodamine B protein cell survival assay (SRB); while cytotoxicity test for pure isolated compounds was carried out in Tieräztlich Hochschule Hannover University, Germany using tetrazolium cell proliferation assay (MTT) on two different cancer cell lines : breast cancer cell line (MCF-7), human liver carcinoma cell line (HEPG-2).

\section{Fractionation of EtOAc extract}

$0.523 \mathrm{~g}$ of EtOAc extract was partitioned between hexane and $80 \%$ aqueous $\mathrm{MeOH}$. Aqueous $\mathrm{MeOH}$ fraction was diluted to $60 \%$ aqueous $\mathrm{MeOH}$ by addition of water and extracted with $\mathrm{CHCl}_{3}$ then chloroform was Evaporated under reduced pressure using rotatory evaporator.

$80 \mathrm{~g}$ of activated silica gel (mesh 63-200 $\mu \mathrm{m}$ Fluka 60741) was packed in glass column $(3 \mathrm{~cm}$ in diameter and $40 \mathrm{~cm}$ height). $0.29 \mathrm{~g}$ of $\mathrm{CHCl}_{3}$ extract was dissolved in $1 \mathrm{ml}$ of $\mathrm{CHCl}_{3}$ and loaded on the top of the silica gel column and then eluted by solvents with different polarities starting with hexane: chloroform: ethyl acetate 1:2:1/2; till $100 \%$ Ethyl acetate and finally with Ethyl acetate: Methanol 5:1- 1:1). According to the polarities of compound, the eluted fractions were categorized into 8 groups using precoated Thin Layer Chromatography (TLC) $(20 \mathrm{~cm} \times 20 \mathrm{~cm}$ with fluorescent indicator Fluka 60778) using chloroform: ethyl acetate 1:1 as solvent system. Purified individual compounds were isolated by preparative TLC using chloroform: ethyl acetate 1:1 as solvent system and then tested for their effectiveness against MCF-7 and HEPG-2 cell lines.

\section{Structure elucidation and characterization of pure compounds}

Structure elucidation and characterization of positive tested compounds using Gas chromatography / mass spectroscopy (GC/MSQP 2010 Plus) and NMR (The NMR spectra were recorded on a Varian Mercury VX-300 NMR spectrometer. $1 \mathrm{H}$ spectra were run at $300 \mathrm{MHz}$ was run at $75.46 \mathrm{MHz}$ in deuterated chloroform $\left(\mathrm{CDCl}_{3}\right)$. Chemical shifts are quoted in $\delta$ and were related to that of the solvents) used for identification of our compounds.

\section{Results and Discussion}

Cytotoxicity test was carried out for EtOAc crude extract on two different cancer cell lines Mcf-7 cell line; HEPG-2 cell line in Vacsera, Egypt using SRB cell survival assay. The cytotoxicity assay confirmed that crude extract can inhibit the proliferation and survival of the two tested cell line types. It was illustrated that there is no significant difference between half minimal inhibitory concentration $\left(\mathrm{IC}_{50}\right)$ exhibited by both cell lines. IC $_{50}$ of the MCF-7 cell line and HEPG-2 cell line was 147.8753 and $150.7043 \mu \mathrm{g} / \mathrm{ml}$ respectively. The toxicity showed by EtOAc crude extract was in accordance with results obtained by [9], where they reported the toxicity of $C$. globosum EtOAc crude extract grown on PDA media for 28 days at $27^{\circ} \mathrm{C}$.

Fractionation of ethyl acetate crude extract was carried out using silica gel column chromatography. The fractions eluted from the column were categorized according to the compound polarities using precoated TLC into 8 groups (A, B, C, D, E, F, G and H) using hexane: chloroform: ethyl acetate as solvent system with different ratios.
Purification of individual compounds from the most effective fraction (G) was carried out using preparative TLC. The purified compounds obtained from preparative TLC were checked on precoated TLC. By calculating $\mathrm{Rf}$ value of the pure compounds obtained compound 1 was at $\mathrm{Rf} 0.66$ while compound 2 at $\mathrm{Rf} 0.55$.

Testing the anticancer activity against MCF-7 and HEPG-2 cancer cell lines were carried out for the purified compounds (compound 1 and compound 2) in Tieräztlich Hochschule Hannover University, Germany using MTT cell proliferation assay. The results showed that $\mathrm{IC}_{50}$ of compound 1 and 2 on MCF-7 are 136.59 and $151.68 \mu \mathrm{g} / \mathrm{ml}$ while, $\mathrm{IC}_{50}$ of compound 1 and 2 on HEPG-2 are 119.3 and 118.93 $\mu \mathrm{g} / \mathrm{ml}$ respectively. Figure 1 showed the inhibitory effect of different concentrations of compound 1 and 2 on the proliferation of and survival of both tested cell lines in comparison with controls.

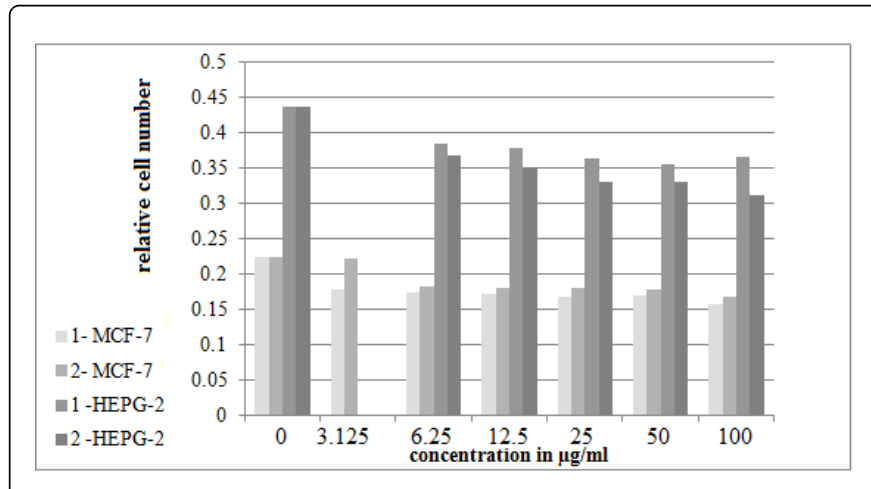

Figure 1: Effect of compound (1) and compound (2) on both MCF-7 and HEPG-2 cell lines.

Structure elucidation of compound 1 and 2<smiles>CCOC(=O)[C@@]1(O)Cc2oc3cccc(O)c3c(=O)c2C=C[C@H]1O</smiles>

Compound 2<smiles>COC(=O)C(O)/C=C/CC(C)(C)C</smiles>

Figure 2: Structure of (compound 1), Methyl 9-dihydro- 8trihydroxy-9-oxo-H-xanthene-1-carboxylate and (compound 2) (E)-methyl 2-hydroxy-6, 6-dimethyl hept-3-enoate. 
Compound 1 was obtained as a pale yellow solid $\mathrm{C}_{15} \mathrm{H}_{12} \mathrm{O}_{7}$ by a combination of GC/MS and H NMR. GC/MS M+ $307 \mathrm{~m} / \mathrm{z}$ and $\mathrm{H}$ NMR spectral data of $1\left(\right.$ in $\left.\mathrm{CDCl}_{3}\right)$ revealed the presence of three aromatic protons in an AMX spin system $[\delta 7.66(\mathrm{t}, \mathrm{J}=8.3 \mathrm{~Hz}), 7.07(\mathrm{~d}$, $\mathrm{J}=8.3 \mathrm{~Hz})$, and $6.81(\mathrm{~d}, \mathrm{~J}=8.3 \mathrm{~Hz})]$, two olefinic protons $[\delta 6.62(\mathrm{dd}$, $\mathrm{J}=10.0,403 \mathrm{~Hz})$ and $6.49(\mathrm{~d}, \mathrm{~J}=10.0)]$, two hydroxyl groups $[\delta 5.85(\mathrm{~d}$, $\mathrm{J}=8.4 \mathrm{~Hz}$ ) and $5.70(\mathrm{br} \mathrm{s})]$, a proton attached to an oxygenated carbon $[\delta 4.26(\mathrm{dd}, \mathrm{J}=8.4,4.3 \mathrm{~Hz})]$, and a methoxy group $(\delta 3.58)$. on the basis of chemical shifts, coupling constants and HMBC correlations, the two olefinic protons, two hydroxyl groups, and the proton attached to an oxygenated carbon were assigned to a $-\mathrm{CH}=\mathrm{CH}-\mathrm{CH}(\mathrm{OH})-\mathrm{C}(\mathrm{OH})$ spin system with $\mathrm{Z}$ configuration of the double bond.

Compound 2 was obtained with no color solid $\mathrm{C}_{10} \mathrm{H}_{18} \mathrm{O}_{2}$ by a combination of GC/MS and H NMR. GC/MS M+170 m/z and H NMR spectral data of $2\left(\right.$ in $\left.\mathrm{CDCl}_{3}\right)$ revealed the presence of two olefinic protons $[\delta 6.62(\mathrm{dd}, \mathrm{J}=10.0,403 \mathrm{~Hz})$ and $6.49(\mathrm{~d}, \mathrm{~J}=10.0)]$, one hydroxyl groups $[\delta 5.85(\mathrm{~d}, \mathrm{~J}=8.4 \mathrm{~Hz})]$, a proton attached to an oxygenated carbon $[\delta 4.26(\mathrm{dd}, \mathrm{J}=8.4,4.3 \mathrm{~Hz})]$, and a methoxy group $(\delta$ 2.2). H NMR of compound 2 was very similar to compound 1 but without aromatic protons. These results are with agreement with [9] (Figure 2).

\section{References}

1. Kirk PM, Cannon PF, Minter DW, Stalpers JA (2008) Dictionary of the Fungi. (10thedn), Wallingford, UK.

2. Sharma R, Kulkarni G, Sonawane MS, Shouche YS (2013) A new endophytic species of Chaetomium from Jatropha podagrica, Mycotaxon. 124: 26-117.

3. Fraenkel GS (1959) The raison d'ětre of secondary plant substances; these odd chemicals arose as a means of protecting plants from insects and now guide insects to food. Science 129: 1466-1470.

4. Isaka M, Jaturapat A, Rukseree $K$, Danwisetkanjana $K$, Tanticharoen $M$, et al. (2001) Phomoxanthones A and B, novel xanthone dimers from the endophytic fungus Phomopsis species. J Nat Prod 64: 1015-1018.

5. Yamada T, Muroga Y, Jinno M, Kajimoto T, Usami Y, et al. (2011) New class azaphilone produced by a marine fish-derived Chaetomium globosum. The stereochemistry and biological activities. Bioorg Med Chem 19: 4106-4113.

6. Awad NE, Kassem HA, Hamed MA, El-Naggar MA, El-Feky AM (2014) Bioassays guided isolation of compounds from Chaetomium globosum. J Mycol Med 24: 35-42.

7. Qin JC, Zhang YM, Gao JM, Bai MS, Yang SX, et al. (2009) Bioactive metabolites produced by Chaetomium globosum, an endophytic fungus isolated from Ginkgo biloba. Bioorg Med Chem Lett 19: 1572-1574.
8. Wang Y, Xu L, Ren W, Zhao D, Zhu Y, et al. (2012) Bioactive metabolites from Chaetomium globosum L18, an endophytic fungus in the medicinal plant Curcuma wenyujin. Phytomedicine 19: 364-368.

9. Kithsiri Wijeratne EM, Turbyville TJ, Fritz LWA, Whitesell L, et al. (2006) A new dihydroxanthenone from a plant-associated strain of the fungus Chaetomium globosum demonstrates anticancer activity Bioorg. Med. Chem. 14: 7917-7923.

10. Sekita S, Yoshihira K, Natori S, Kumano H (1973) Structures of chaetoglobosin A and B, cytotoxic metabolites of Chaetomium globosum Tetrahedron Lett. 23: 2109-2112.

11. Sekita S, Yoshihira K, Natori S, Kumano H (1979) X-ray analysis of chaetoglobosin A, an indol-3-yl-[13]cytochalasan from Chaetomium globosum Tetrahedron Lett. 17: 1351-1354.

12. Sekita S, Yoshihira K, Natori S, Kumano H (1977) Rearrangement and tans -elimination against the chugaev reaction rule Tetrahedron Lett. 32: 2771-2774.

13. Jiao W, Feng Y, Blunt JW, Cole AL, Munro MH (2004) Chaetoglobosins $\mathrm{Q}, \mathrm{R}$, and T, three further new metabolites from Chaetomium globosum. J Nat Prod 67: 1722-1725.

14. Probst A, Tamm Ch (1981) 19-O-Acetylchaetoglobosin B and 19-OAcetylchaetoglobosin D, Two New Metabolites of Chaetomium globosum Helv. Chim. Acta. 64: 2056-2964.

15. Tanida S, Tsuboya S, Harada S (1992) Jpn Kokai Tokkyo Koho.

16. Itoh Y, Kodama K, Furuya K, Takahashi S, Haneishi T, et al. (1980) A new sesquiterpene antibiotic, heptelidic acid producing organisms, fermentation, isolation and characterization. J Antibiot (Tokyo) 33: 468-473.

17. Kikuchi T, Kadota S, Nakamura K, Nishi A, Taga T, et al. (1982) Chem. Pharm. Bull. 30: 3846-3848.

18. Takahashi M, Koyama K, Natori S (1990) Chem. Pharm. Bull. 38: 625-628.

19. Breinholt J, Demuth H, Morten J, Georg W, Moeller IL, et al. (1996) Prenisatin (5-(3-Methyl-2-butenyl)-indole-2,3-dione): an Antifungal Isatin Derivative from Chaetomium globosum. Acta. Chem. Scand. 50: 443-445.

20. Tabata Y, Miike N, Yaguchi T, Hatsu M, Ishii S, et al. (2000) Phylogeny, identification and nomenclature of the genus Aspergillus. Studies in Mycology 39: 55-64.

21. Kanokmedhakul S, Kanokmedhakul K, Phonkerd N, Soytong K, Kongsaeree P, et al. (2002) Antimycobacterial anthraquinonechromanone compound and diketopiperazine alkaloid from the fungus Chaetomium globosum KMITL-N0802. Planta Med 68: 834-836.

22. Moubasher AH (1993) Soil Fungi in Qatar and Other Arab Countries, The scientific and Applied Research center University of Qatar 131-140. 